\title{
CTSV Gene
}

National Cancer Institute

\section{Source}

National Cancer Institute. CTSV Gene. NCI Thesaurus. Code C114303.

This gene plays a role in protein catabolism. 